\title{
顎の対向関係位の設定に関する基礎的研究
}

臨床経験度による鼻根一上唇下顎間距離測定 2 法の比較検討

$$
\text { 小林 弘樹* 村岡博** }
$$

\section{A Influence of the Discrepancies in the Vertical Dimension Measurements Obtained by Skilled Operators and Beginners using Dento-Profile Technique and Conventional Methods}

\author{
Hiroki Kobayashi* and Hiroshi Muraoka**
}

For the two measuring methods of occlusal vertical dimension using Dento-Profile and Willis techniques, four operators having different degrees of skill obtained measurements using these techniques from 20 subjects and these measurements were then compared. It was found that in either case of the techniques used, there were no substantial differences in measurements obtained by the skilled operators.

However, in case of Willis technique, the measurements taken by the other operators showed a considerably great difference from one another. In case of Dent-Profile technique, only a small difference was shown among all the measurements obtained. The above results indicate that the measurement using Dento-Profile technique may allow operators to secure almost the same clinical values, irrespective of the degrees of operators'skill.

\section{緒言}

総義歯製作時には必ず咬合高径を決定，採得す る作業を行わねばならない.一般臨床における総 義歯製作の術式において，この作業は咬合採取時 に行われる事が多い.しかしわれわれの行ってい るテンタティブ・デンチャー法においては, テン タティブ・デンチャー作製，修正時に何回も咬合 高径を測定する必要がある ${ }^{1,2)}$.このため簡便で正 確な咬合高径決定法が必要となる。

過去われわれのオフィスでは, 坪根式バイト ゲージを用いてウイリス法で咬合高径の測定を 行っていだ）(図 1 )。この方法は, 咬合状態で患

* 東京都中央区勤務

** 東京都中央区開業
者が目を開け真っ直ぐ前を見た時の黒目の中心 (鼻根点)から口角までの距離と, 鼻下点から頣点 までの距離を測定し，それらの值が等しければ理 想的な咬合高径であるというものである ${ }^{4}$. しか

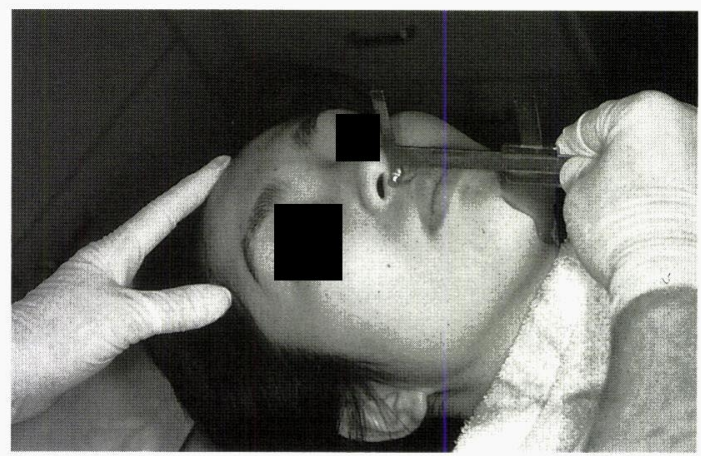

図 1 ウイリス法 


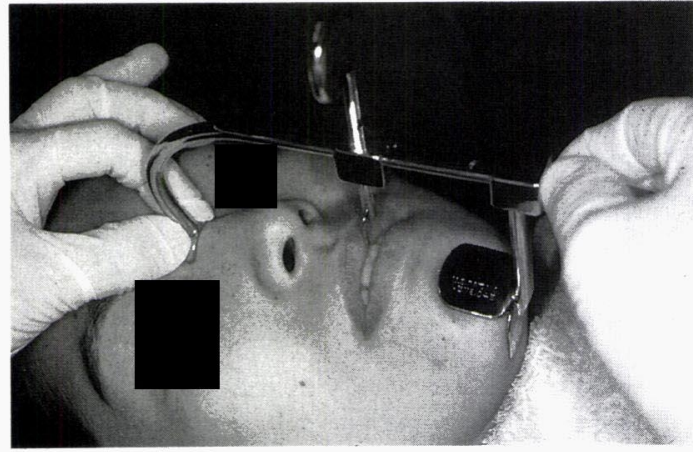

図 2 デントプロフィール法

しこの方法は，皮膚の表面およびフリーハンドで 測定を行うため, 術者の熟練度によって誤差が生 じやすい.つまり皮膚に対する器具の当て方，值 を読み取る目線の角度等により計測值に誤差が出 る可能性があるからである.

現在われわれは，デントプロフィール・スケー ルを用いた，デントプロフィール法を採用し測定 を行っている。この方法は咬合状態で, 鼻根点(患 者が目を開いて真っ直ぐ前を見た時の左右の黒目 の中心を結んだ線と鼻筋の中心が交叉した点）か ら鼻下点までの距離と, 鼻根点から上唇下縁まで の距離を足したものが鼻根点から頤点までの距離 と等しければ理想的な咬合高径であると言うもの である5（図 2 ).ウイリス法に対しデント・プロ フィール法は，皮膚上で計測する事には代わりは ないが, 器具をしっかりと顔面に固定し, 計測值 を読み取るので計測值の誤差が出にくくなってい る.

本研究はウイリス法とデントプロフィール法を 用いて，測定法と熟練度の相違が咬合高径測定誤 差に及ぼす影響を検討し両測定法を比較すること を目的とする。

\section{方法}

2 種類の測定方法の比較を行うために，基準点 を共有する事とした。このため顔面上に 4 つの基 準点 ( a : 鼻根点, b : 鼻下点, $\mathrm{c}$ ：口角および 上唇下縁， $\mathrm{d}$ : 願点）を設け，それらを結ぶ 4 つ の基準距離 $(\mathrm{A}$ ：鼻根点から鼻下点, $\mathrm{B}$ ：鼻根点

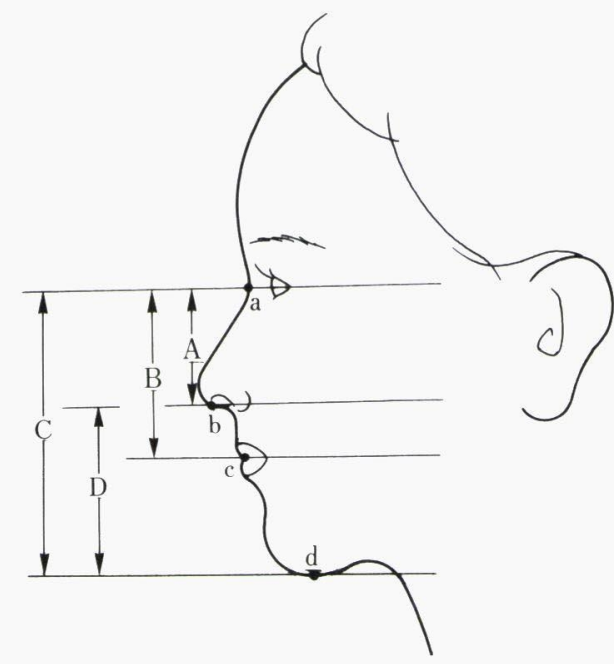

図 3 顔面上の基準点. (鶴木 隆：顎咬 合不全と顎矯正外科. 保母ら「咬 合学」, P 487, クインテッセンス 出版, (東京), 1995. より改変)

から口角および上唇下縁, $\mathrm{C}$ ：鼻根点から頤点, $\mathrm{D}$ ：鼻下点から願点）を設けた（図 3 ）。ここで口 角および上唇下縁は, 顔面に対し垂直方向から測

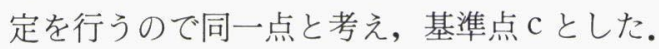

ウイリス法によれば， $\mathrm{B}$ と D 測定し， $\mathrm{B}=\mathrm{D}$ であれば理想的な咬合高径である。

デント・プロフィール法によれば， A， B ， C

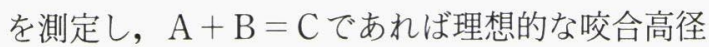
である。

デントプロフィール法と, ウイリス法を比較す るために共通する B の計測値を用い比較する事と した。そして異なる熟練度の術者 4 人により被験 者 20 人について測定を行った.

ドクターA：臨床歴 50 年.

ウイリス法での測定数十年, デントプロフィー ル法 3 年.

ドクターB：臨床歴 7 年.

ウイリス法での測定 4 年, デントプロフィール 法 3 年.

アシスタントA：臨床歴 10 年.

ウイリス法での測定 0 年, デントプロフィール 法 0 年.

アシスタント B : 臨床歴 6 カ月. 
表 1 デントプロフィール法による测定結果.

(単位 $\mathrm{mm}$ )

\begin{tabular}{c|c|c|c|c}
\hline 被験者 & 術者 $\mathrm{A}$ & $\mathrm{B}$ & $\mathrm{C}$ & $\mathrm{D}$ \\
\hline 1 & 74.5 & 74.5 & 75.5 & 76.0 \\
2 & 70.0 & 71.0 & 71.5 & 71.5 \\
3 & 72.0 & 73.0 & 73.5 & 72.0 \\
4 & 69.5 & 69.5 & 70.5 & 71.5 \\
5 & 71.0 & 71.0 & 72.5 & 71.5 \\
6 & 70.0 & 71.0 & 71.0 & 71.5 \\
7 & 75.0 & 74.0 & 76.0 & 76.0 \\
8 & 73.5 & 74.5 & 74.5 & 75.0 \\
9 & 72.0 & 72.0 & 73.0 & 73.5 \\
10 & 74.0 & 74.0 & 74.0 & 74.5 \\
11 & 74.5 & 75.5 & 75.5 & 75.5 \\
12 & 72.5 & 73.0 & 73.5 & 73.5 \\
13 & 73.0 & 73.5 & 74.0 & 74.0 \\
14 & 70.0 & 70.0 & 71.0 & 70.0 \\
15 & 71.5 & 72.0 & 73.0 & 72.5 \\
16 & 74.5 & 74.5 & 75.0 & 75.0 \\
17 & 73.5 & 73.5 & 74.0 & 74.0 \\
18 & 72.0 & 72.5 & 72.5 & 72.0 \\
19 & 74.0 & 74.0 & 74.5 & 74.0 \\
20 & 73.0 & 73.0 & 73.0 & 73.5 \\
\hline
\end{tabular}

ウイリス法での測定 0 年, デントプロフィール 法 0 年.

どちらの方法も咬合状態で測定を行うものなの で, 被験者は有歯顎で咬合状態のしつかり確保さ れているもの 20 名を選んだ。

\section{結 果}

結果を表 1 および 2 に示す。

表 1 および 2 のデー夕を統計処理した結果は, 次の通りである。

1.デントプロフィール法の測定結果に対する ウイリス法の测定結果の相対䛊差は術者 $\mathrm{A}, \mathrm{B}$, C およびDについてそれぞれ平均一 $0.15 \pm 0.33$ $\mathrm{mm},-0.43 \pm 0.63 \mathrm{~mm}, \quad 1.83 \pm 1.48 \mathrm{~mm}$ および $1.50 \pm 1.56 \mathrm{~mm}$ で, 相対䛊差の平均值（絶対值で 比較）および標準偏差值のいずれにおいても測定 の熟練度（A>B >C $\quad$ D）が低いほど值が大き くなった。
表 2 ウイリス法による測定結果.

(単位：mm)

\begin{tabular}{c|c|c|c|c}
\hline 被験者 & 術者 $\mathrm{A}$ & $\mathrm{B}$ & $\mathrm{C}$ & $\mathrm{D}$ \\
\hline 1 & 74.5 & 74.5 & 78.0 & 77.5 \\
2 & 70.0 & 70.5 & 75.0 & 72.0 \\
3 & 71.5 & 71.0 & 73.0 & 74.0 \\
4 & 69.5 & 68.5 & 73.0 & 71.5 \\
5 & 70.5 & 71.0 & 75.0 & 75.0 \\
6 & 70.0 & 70.0 & 75.0 & 72.5 \\
7 & 75.0 & 74.5 & 76.5 & 78.0 \\
8 & 73.0 & 73.5 & 77.0 & 76.0 \\
9 & 72.0 & 72.0 & 76.0 & 76.0 \\
10 & 74.0 & 73.0 & 75.0 & 76.0 \\
11 & 74.0 & 75.0 & 77.0 & 77.5 \\
12 & 72.5 & 73.0 & 76.0 & 75.5 \\
13 & 73.5 & 73.5 & 77.0 & 75.0 \\
14 & 70.0 & 71.0 & 72.5 & 71.5 \\
15 & 71.0 & 72.0 & 75.0 & 72.5 \\
16 & 74.5 & 74.5 & 78.0 & 76.0 \\
17 & 73.0 & 74.0 & 75.5 & 75.0 \\
18 & 71.5 & 72.0 & 74.5 & 75.5 \\
19 & 73.5 & 74.0 & 77.0 & 76.5 \\
20 & 72.5 & 72.0 & 74.0 & 76.5 \\
\hline
\end{tabular}

2.ウイリス法において，術者 $\mathrm{A}$ の測定結果に 対する他の術者の測定結果の相対器差は, 術者 B, $\mathrm{C}$ および $\mathrm{D}$ にいてそれぞれ平均 $0.18 \pm 0.63$ $\mathrm{mm}, 3.18 \pm 1.15 \mathrm{~mm}$ および $2.83 \pm 0.95 \mathrm{~mm}$ で, 特に平均値において熟練者 (B) と非熟練者（C およびD）の間に顕著な相違がみられた。

3.デントプロフィール法において，術者 $\mathrm{A} の$ 測定結果に対する他の術者の測定結果の相対誤差

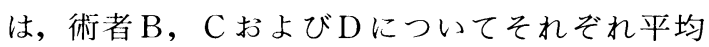
$0.30 \pm 0.52 \mathrm{~mm}, \quad 0.90 \pm 0.45 \mathrm{~mm}, \quad 0.85 \pm 0.61 \mathrm{~mm}$ で，ウイリス法における結果と比べて特に非熟練 者（CおよびD）における相対詰差の平均值が約 3 分の 1 , 標準偏差值も約 2 分の 1 に減少した。

\section{考察}

異なる熟練度の術者による，顔面上の 2 点間の 距離の計測を 2 種類の器具で行った。臨床経験 50

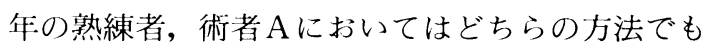


計測值にほとんど差がなかった.ウイリス法とデ ントプロフィール法の計測值に差がみられたのは 20 人中 10 人で，䛊差は $0.5 \mathrm{~mm}$ 以内であった. 臨床的に肉眼で計測值を読み取るためこの 0.5 $\mathrm{mm}$ が検知限界と考えられる。そこで，この術者 $\mathrm{A}$ の計測值を基準として他の計測值との比較を 行った.

ウイリス法において術者の熟練度により，かな りの計測值の差が見られた。術者 $\mathrm{A}$ と比較し計測 値の異なったものは, 術者 $\mathrm{B}$ は 20 人中 15 人で最 大 $1.0 \mathrm{~mm}$ の差, 術者 $\mathrm{C}$ は 20 人中 20 人で最大 $5.0 \mathrm{~mm}$ の差, 術者 $\mathrm{D}$ は 20 人中 20 人で最大 4.5 $\mathrm{mm}$ の差で, 熟練度による差は最大 $5.0 \mathrm{~mm}$ で あった。

統計処理の結果を見ても，測定誤差の平均値に おいて熟練者（B）と非熟練者（CおよびD）の 間に約 10 倍の差違が認められたのでウイリス法 による計測誤差を少なくするためにはかなりの経 験が必要であると考えられる。

デントプロフィール法では, 術者 $\mathrm{A}$ と比較し計 測値の異なったものは，術者 $\mathrm{B}$ は 20 人中 10 人で 最大 $1.0 \mathrm{~mm}$, 術者 $\mathrm{C}$ は 20 人中 18 人で最大 1.5 $\mathrm{mm}$, 術者 $\mathrm{D}$ は 20 人中 16 人で最大 $1.5 \mathrm{~mm}$ の差 で, 熟練度による差は最大 $1.5 \mathrm{~mm}$ 以内であった。 術者 $\mathrm{C}, \mathrm{D}$ の $\mathrm{A}$ との最大の差は $1.5 \mathrm{~mm}$ である.

統計処理の結果を見ると，熟練者（B）ではウ イリス法とデントプロフィール法で有意差は認め られないものの, 非熟練者（CおよびD）ではウ イリス法からデントプロフィール法に切り替える ことにより, 測定誤差が平均值で約 3 分の 1 に減
少し, ばらつきも約 2 分の 1 と顕著な減少効果を 示した。デントプロフィール法においても熟練者 （B）と非熟練者（CおよびD）の間ではまだ 3 倍 の差を残しているが, 測定誤差の大きさは非熟練 者でも平均 $1 \mathrm{~mm}$ 以下（標準偏差值は約 $0.5 \mathrm{~mm}$ ) になった。

\section{結 論}

2 つの咬合高径測定法, ウイリス法とデントプ ロフィール法を比較した結果, 熟練者においては 有意な差は見られないが, 非熟練者の場合には, ウイリス法にくらベデントプロフィール法の測定 誤差は平均值で約 3 分の 1 , ばらつきで約 2 分の 1 になることがわかった。

\section{参考文献}

1）村岡 博：コンプリートデンチャーの製作。第 1版：83-100,クインテッセンス(東京), 1988.

2) 村岡 博: 総義歯臨床 120 のポイント. 第 1 版：105 -108, 日本歯科評論社（東京），1993.

3）村岡 博：コンプリートデンチャーの製作。第 1版：87，クインテッセンス (東京), 1988.

4）坪根政治, 豊田静夫：総義歯臨床形態学. 第 1 版：157-159, 医歯薬出版 (東京), 1978.

5）坪根政治，豊田静夫：総義歯臨床形態学. 第 1 版：157-158, 医歯薬出版 (東京), 1978 .

別刷請求先：小林弘樹

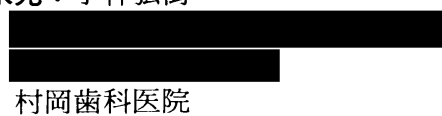

